\title{
Spatial assessment of albatrosses, commercial fisheries, and bycatch incidents on Canada's Pacific coast
}

\author{
C. H. Fox ${ }^{1,5, *}$, C. Robertson ${ }^{2}$, P. D. O'Hara ${ }^{3}$, R. Tadey ${ }^{4}$, K. H. Morgan ${ }^{3}$ \\ ${ }^{1}$ Department of Oceanography, Dalhousie University, Halifax, NS B3H 4R2, Canada \\ ${ }^{2}$ Department of Geography and Environmental Studies, Wilfrid Laurier University, Waterloo, ON N2L 3C5, Canada \\ ${ }^{3}$ Canadian Wildlife Service, Environment and Climate Change Canada, Institute of Ocean Sciences, Sidney, BC V8L 4B2, Canada \\ ${ }^{4}$ Fisheries and Oceans Canada, Vancouver, BC V6C 3S4, Canada \\ ${ }^{5}$ Present address: Canadian Wildlife Service, Environment and Climate Change Canada, Nanaimo, BC V9R 5H7, Canada
}

\begin{abstract}
Fisheries bycatch mortality poses a primary threat to the majority of the world's 22 albatross species, 15 of which are at risk of extinction. Although quantitative estimates of albatross bycatch are often unavailable due to a relative or total absence of monitoring, spatial overlap between fisheries and albatrosses is often used to estimate the extent of interaction, a proxy for exposure to bycatch, and to inform avoidance and mitigation actions. Using comprehensive records of commercial demersal longline and trap fishing and survey information for albatrosses (black-footed albatross Phoebastria nigripes, Laysan albatross P. immutabilis, short-tailed albatross $P$. albatrus), the extent of spatial potential interaction was estimated in Canada's Pacific coast waters and examined across breeding and non-breeding seasons. The distributions of albatrosses and longline and trap fisheries were found to substantially overlap, with potential interaction hotspots concentrated along the continental shelf break. Trap fisheries reported 1 albatross bycatch incident, suggesting that these fisheries are responsible for negligible albatross mortalities. In contrast, $>80 \%$ of recorded albatross bycatch incidents occurred within $10 \mathrm{~km}$ of albatrosslongline fisheries hotspot locations, providing evidence that albatross-longline potential interaction hotspots represent actual areas of elevated bycatch mortality risk. Indicative of potential conservation concern, $60 \%$ of short-tailed albatross sightings occurred within $10 \mathrm{~km}$, and $93 \%$ within $30 \mathrm{~km}$, of albatross-longline potential interaction hotspots. By contributing knowledge regarding albatross-fisheries interactions, in addition to undertaking the first evaluation of albatrossfisheries hotspots with recorded bycatch incidents on Canada's Pacific coast, this study represents a step towards enhancing albatross conservation through bycatch avoidance and mitigation.
\end{abstract}

KEY WORDS: Albatross $\cdot$ Seabird $\cdot$ Commercial fishing $\cdot$ Bycatch $\cdot$ Spatial interaction $\cdot$ Conservation

\section{INTRODUCTION}

The world's oceans, of critical importance to global nutrient cycles, climate regulation, biodiversity, and socio-economic systems, have been fundamentally altered by humans (Jackson et al. 2001). Widespread and often intense commercial fisheries represent a leading anthropogenic driver of change across the planet's marine ecosystems (Halpern et al. 2008,

\footnotetext{
${ }^{*}$ Corresponding author: caroline.fox@ec.gc.ca
}

2019), with a lengthy and often underappreciated historical legacy (Jackson et al. 2001). In addition to direct exploitation (e.g. Myers \& Worm 2003, Roman \& Palumbi 2003), pervasive ecological consequences have been documented (e.g. Pace et al. 1999, Frank et al. 2005, Anthony et al. 2008).

Top predators are impacted by fisheries through altered and degraded ecosystems (Tasker et al. 2000, Wasser et al. 2017) and direct exploitation (Awker2021. Open Access under Creative Commons by Attribution Licence. Use, distribution and reproduction are unrestricted. Authors and original publication must be credited. 
man et al. 2006, Campbell et al. 2009, Robards \& Reeves 2011). Additionally, seabirds, cetaceans, and turtles are unintentionally killed in fisheries worldwide (Lewison et al. 2004, 2014). Considerable progress has been achieved in the development and implementation of modified gear and fishing practices to reduce the incidental take of non-target taxa (e.g. Hall \& Mainprize 2005, Anderson et al. 2011, Senko et al. 2014, Domingo et al. 2017). Despite this progress, bycatch remains a significant driver of seabird, cetacean, and turtle population declines and recovery failures, and directly threatens the persistence of numerous species worldwide (e.g. multiple albatross species: Arnold et al. 2006, Jiménez et al. 2014, Bakker et al. 2018; North Atlantic right whale Eubalaena glacialis: Knowlton et al. 2012; vaquita Phocoena sinus: Taylor et al. 2017; leatherback turtle Dermochelys coriacea: Roe et al. 2014).

Many seabirds, especially those in the order Procellariiformes, are attracted to fishing vessels, often from considerable distances. For example, Collet et al. (2015) and Soriano-Redondo et al. (2016) reported that Procellariiformes species are attracted to fishing fleets up to $30 \mathrm{~km}$ away. Largely due to the propensity of seabirds to investigate fishing vessels in search of food, hundreds of thousands of seabirds are killed in fisheries each year (Brothers et al. 2010, Anderson et al. 2011, Žydelis et al. 2013), including gillnet, longline, seine, trawl, and trap fisheries (reviewed by Pott \& Wiedenfeld 2017). Mortalities occur when birds seize baited hooks or are hooked by the bill or body and subsequently drown; become entangled and drown in nets, lines, and cables; and collide with vessel wires and cables, as well as through other means (Bartle 1991, Tasker et al. 2000, Løkkeborg 2011). Importantly, not all bird-fisheries interactions are negative; fisheries bait and discards provide a reliable food resource for some seabirds (Tasker et al. 2000, Wagner \& Boersma 2011), with evidence of positive associations between certain scavenging seabird populations and discard release (Furness 2003).

Although estimates are uncertain, a substantial component of global seabird bycatch is attributable to longline fisheries (160000-360000 birds $\mathrm{yr}^{-1}$ or more), with albatrosses ranking among the most frequently caught taxa (Anderson et al. 2011). Longlived, with long maturation times and low fecundity, albatrosses are among the most threatened of the world's birds (Croxall et al. 2012). Of the world's 22 albatross species, 15 are threatened with extinction, with the remaining 7 considered near threatened; a primary threat faced by the majority of these species is fisheries bycatch mortality (Phillips et al. 2016).
In Canada's Pacific coast waters, quantitative estimates of albatross bycatch in commercial fisheries are not available due to incomplete monitoring and reporting and a relative lack of species-specific seabird identification of bycatch. However, previous research has identified the black-footed albatross Phoebastria nigripes as the most frequently reported seabird species in British Columbia's commercial demersal longline fisheries (hereafter longline fisheries; Smith \& Morgan 2005). Deployment of bycatch deterrents, requirements of the fishing licenses, was phased in on commercial longline fisheries between 2002 and 2005, depending on the fishery (R. Tadey, Fisheries and Oceans Canada, pers. comm. July 2020). When setting longline gear, vessels are required to deploy at least 1 streamer (tori) line that extends at least $30 \mathrm{~m}$ beyond where the groundline enters the water, with a buoy attached at the terminal end to maximize the tori line's aerial extent, plus either a second tori line or an additional towed buoy (e.g. Fisheries and Oceans Canada 2019). Combinations of deterrents, such as tori lines along with other measures (e.g. weighted hooks), have been demonstrated to reduce seabird bycatch in commercial longline fisheries (Løkkeborg 2011, Melvin et al. 2019). However, given recent evidence of low compliance with respect to the mandatory use of tori lines with attached buoys in commercial longline fisheries on Canada's Pacific coast (Dustin De Gagne, Fisheries and Oceans Canada, pers. comm. August 2020), there is conservation concern regarding seabird bycatch in Canadian waters and a need for greater understanding of albatross-fisheries interactions.

Quantitative estimates of bycatch are often lacking due to unreliable, incomplete, or a total absence of monitoring. In these common scenarios, spatial overlap between commercial fisheries and bycatchvulnerable species such as albatrosses is often used to estimate the extent of spatial interaction, a proxy for bycatch risk, and to further resolve where mitigation efforts could reduce bycatch (e.g. Suryan et al. 2007, Petersen et al. 2008, Fischer et al. 2009, Copello et al. 2014, Robertson et al. 2014). Within identified areas of spatial overlap, hotspots of interaction (here meaning areas of elevated fishing effort and albatross densities) can be delineated. We use the term hotspot recognizing that there is no universally accepted definition (Nelson \& Boots 2008) and, further, that the concept of a hotspot may vary based on the research objective, such as species occurrence hotspots (Gaston \& David 1994, Flather et al. 1998, Stahl et al. 2001) and biodiversity hotspots (Myers et al. 2000, Harvey et al. 2017). In this study, we use the 
term hotspot to identify regions where the estimated interaction between albatrosses and fisheries is highest. Risk analyses integrate both exposure (or vulnerability: sensu Zacharias \& Gregr 2005) and sensitivity to a stressor; in this study, we specifically estimate exposure to potential fishery bycatch.

The spatial extent and intensity of potential interaction were estimated in Canada's Pacific coast waters for the breeding and non-breeding seasons using comprehensive records of commercial longline and trap fishing events (i.e. a single fishing set represents 1 fishing event; 2006-2012) and line transect survey information for albatrosses (black-footed albatross, Laysan albatross P. immutabilis, shorttailed albatross P. albatrus; 19822010). We further examine the utility of our approach by comparing potential interaction hotspot locations with locations of actual reported catches of albatrosses (hereafter referred to as albatross bycatch incidents) in longline or trap fisheries. Principle study objectives were fourfold: (1) identify

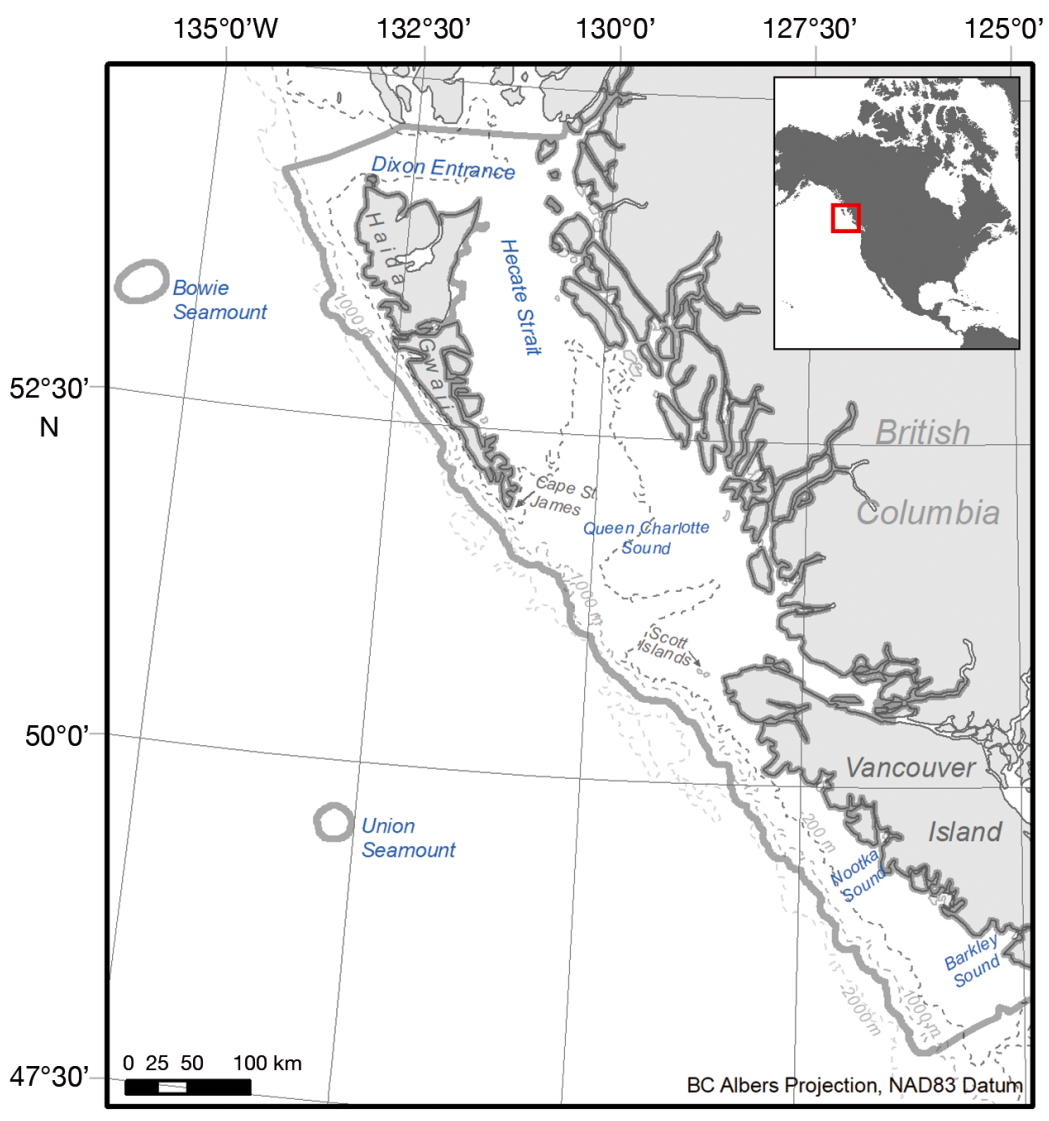

Fig. 1. Study area (123000 km², grey outline) in coastal British Columbia, Canada

areas of spatial overlap between commercial longline and trap groundfish fisheries and albatrosses; (2) identify hotspots of potential interaction, where elevated densities of albatrosses and fishing events cooccur; (3) compare potential interaction hotspots with reported albatross bycatch incidents; and (4) evaluate the proximity of short-tailed albatross sightings with potential interaction hotspots. This study contributes new knowledge regarding the spatial extent and locations of elevated likelihood of albatross-fisheries interactions in Canada's Pacific coast waters and represents a step towards enhanced bycatch avoidance and mitigation measures for albatrosses in Canadian waters.

\section{METHODS}

\subsection{Study area}

The study region was Canada's Pacific coast waters. To identify potential high-risk areas for albatross bycatch, the study area was constrained to locations with a depth of less than 2000 m, including
Bowie and Union seamounts, which lie westward of the continental shelf break (defined in this study as the $200 \mathrm{~m}$ isobath; Fig. 1). See Section 2.4 for information regarding delineation of the approximately $123000 \mathrm{~km}^{2}$ study area.

\subsection{Albatross information}

Two different albatross datasets were combined for this study: the first, an Environment and Climate Change Canada (ECCC) long-term dataset and the second, a relatively short-term (i.e. 2005-2008) but intense systematic survey completed by the Raincoast Conservation Foundation (RCF; Fox et al. 2017). Survey effort was differentiated by the average (in terms of beginning and end dates across species) breeding and non-breeding seasons of 3 North Pacific albatross species, black-footed albatross Phoebastria nigripes, Laysan albatross $P$. immutabilis, and short-tailed albatross $P$. albatrus (breeding: Dec 1-Jun 30; non-breeding: Jul 1-Nov 30; Fig. 2). Although all 3 species occur in Canada's exclusive economic zone (EEZ), black-footed albatrosses are the 

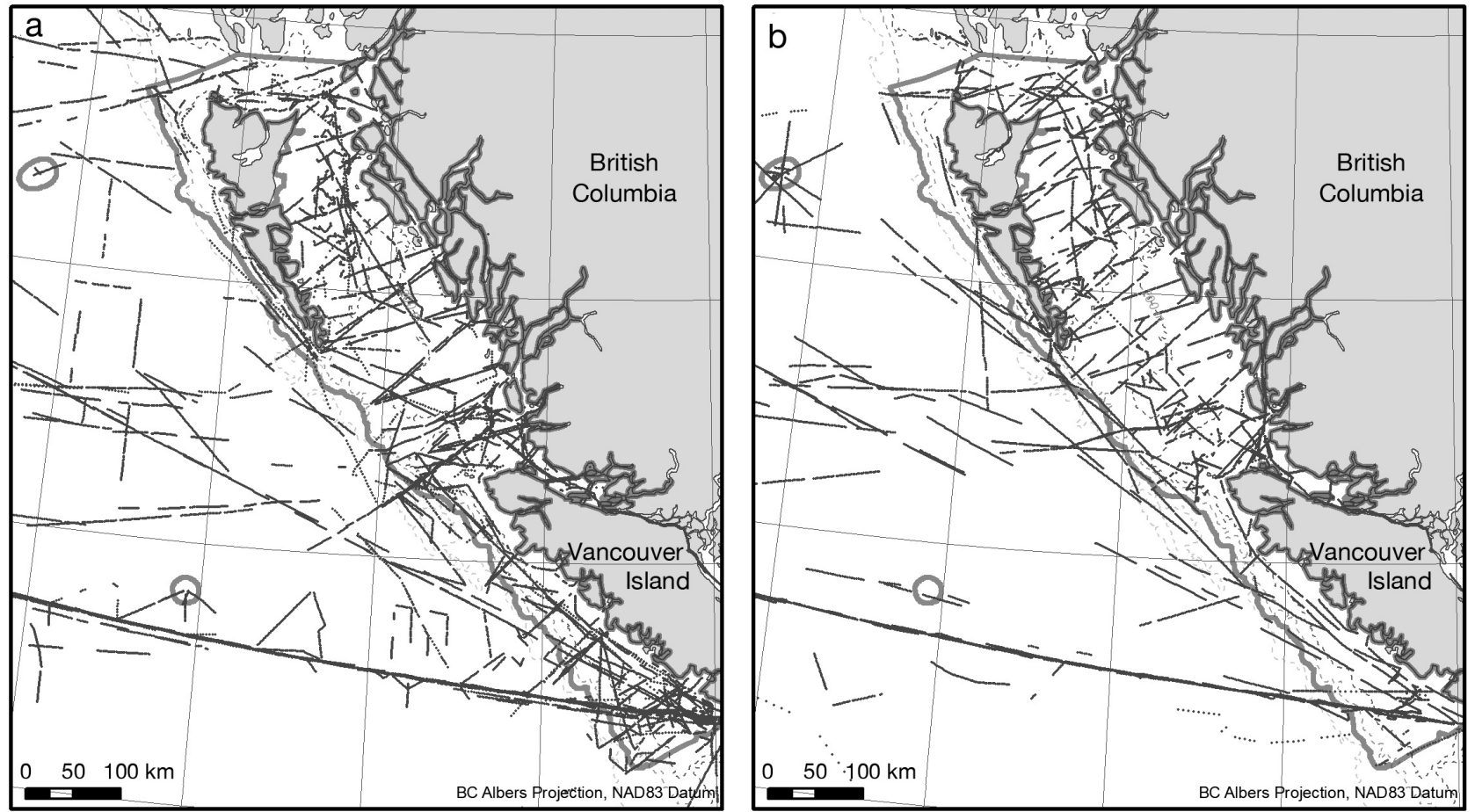

Fig. 2. Distribution of albatross vessel-based survey effort in albatross (a) breeding (Dec 1-Jun 30) and (b) non-breeding (Jul 1-Nov 30) seasons, in and adjacent to the study area (outlined in grey)

most commonly sighted (e.g. Kenyon et al. 2009, Fox et al. 2017).

The first dataset consists of relatively long-term (1982-2010) information collected by ECCC that relied on ships of opportunity seabird surveys off the coast of British Columbia (ECCC unpubl. data, see Kenyon et al. 2009 for details). Although there were variations in survey protocol over that time period, observations were generally made during transects where the surveyed area extended $250 \mathrm{~m}$ outwards from one side of the vessel (side that afforded the best viewing conditions). During each transect, which generally lasted $5 \mathrm{~min}$, all birds sighted within the survey area were counted and recorded to the lowest possible taxonomic resolution. Albatrosses in flight and on the water were counted separately; we combine both behaviours here to derive density estimates (birds $\mathrm{km}^{-2}$ ) for the midpoint of each transect. In this database, approximately $90 \%$ of all albatrosses encountered were black-footed albatrosses, $>9 \%$ were Laysan albatrosses, and $<1 \%$ were shorttailed albatrosses. Given the longevity of this dataset, it is acknowledged that albatross densities and distributions have likely changed over time; this study uses this dataset as the best available information for the study region, and it is indicative of areas of persistent use by albatrosses.
The second dataset consists of a shorter-term (20052008) but intensive systematic line transect survey conducted by RCF (Fox et al. 2017) over continental shelf waters off the central and north coast of British Columbia. Marine bird information was collected using distance sampling along $4729 \mathrm{~km}$ of planned systematic transects and $824 \mathrm{~km}$ of on passage non-systematic transects. Bird species density along $1 \mathrm{~km}$ transect segments were estimated using multiple covariate distance sampling in the software program Distance 6.0 release 2 (Thomas et al. 2010), the package MRDS v2.1.4 (Laake et al. 2013), and the software program R v3.0.2 (R Core Team 2013). For detailed information on the surveys, see Fox et al. (2017). As above, density estimates for albatrosses were provided for birds on the water and in flight for identified blackfooted albatrosses and unknown albatrosses (typically sighted at greater distance from the survey vessel), as black-footed albatrosses dominated sightings during these surveys (i.e. all but 1 identified albatrosses were black-footed albatrosses). Density estimates (birds $\mathrm{km}^{-2}$ ) were combined for birds in flight and on the water along $1 \mathrm{~km}$ transect segments and for the midpoint of each transect segment subsequently used.

A third dataset consists of short-tailed albatross observations (1990-2018, $\mathrm{n}=60$ sightings in the study area). These data were derived from a variety of 
sources including the above-noted at-sea surveys conducted by ECCC and RCF. In addition, we included sightings from trained observers conducting stock assessment surveys for the International Pacific Halibut Commission and from skilled birders and/or birding guides on a variety of platforms, providing they submitted detailed observation notes and/or photographs. The data were used to evaluate cooccurrence and proximity of short-tailed albatross sightings with the longline fisheries and albatross potential interaction hotspots.

\subsection{Fishing effort and bycatch incident information}

Spatial information of commercial groundfish fishing events was provided by Fisheries and Oceans Canada for 2006 to 2012. Commencing in 2006, the commercial groundfish fishery transitioned to an onboard electronic monitoring system (EMS) used across the entire fleet for all fishing activities. Tabular data were converted to spatial data using the centroid locations of each fishing event (i.e. midpoint between where a fishing set began and ended). For fishing events where only the start or end point was recorded $(<1 \%$ of fisheries data), we used that point as the centroid location. Fishing events with erroneous point locations (e.g. on land) or with missing gear types were excluded from analyses. Data were partitioned by fishing gear type (longline or trap) and by albatross reproductive seasons (breeding and non-breeding seasons; Fig. 3).

All commercial fishing effort data for demersal groundfish longline fisheries within the study area that targeted Pacific halibut Hippoglossus stenolepis, sablefish Anoplopoma fimbria, rockfish Sebastes spp. (outside rockfish fishery only; see Fig. 1 in Yamanaka \& Logan 2010 for boundaries), spiny dogfish Squalus suckleyi, and all modified Korean trap fisheries targeting sablefish for all study years were combined into 1 dataset prior to analysis.

Albatross bycatch incidents (presumed to be predominantly mortalities) were included in the fishing database provided by Fisheries and Oceans Canada as an attribute associated with individual fishing events (i.e. individual fishing sets) (Fig. 4c). An albatross bycatch incident is defined as a specific fishing event in which 1 or more albatrosses were caught in either longline or trap fisheries. Available fishing effort information spanned 2006 to 2012; available albatross bycatch information spanned 2006 to 2014 . Reported bycatch incidents from vessel logbooks and EMSs included birds identified as 'black-footed alba- tross', 'albatross species', and 'unidentified albatross'. Based only on the audits of the EMS videos, of the total albatross bycatch incidents encountered, approximately $70 \%$ were identified as black-footed albatross and the remainder as either albatross species or unidentified albatross. An unknown number of albatrosses may have been misidentified, particularly those derived from the logbooks. With no mechanism to validate accuracy, the certainty of identifications should be treated with caution. Bycatch incidents were combined and subsequently used to evaluate whether estimated hotspots of potential interaction represented areas of elevated bycatch risk.

\subsection{Data processing}

A kernel density estimator (KDE) was used to estimate the underlying density distribution of both the fishing events and the albatrosses. Conceptually, the method estimates a continuous surface of observation density from a sample of point data (Silverman 1986) and is widely used for home range mapping in ecology (Worton 1995). As noted by Nelson \& Boots (2008), kernel methods are well suited for hotspot detection via visualization of abundance, scarcity, and variability as well as for integrating auxiliary environmental raster datasets such as elevation or bathymetry. Finally, kernel surfaces support mathematical operations typical of raster analyses that are not possible with vector methods such as minimum convex polygons or alpha hulls.

The first step towards delineating the study area was to identify areas off the British Columbian mainland coast out to the $2000 \mathrm{~m}$ bathymetric contour that represented albatross habitat and/or fishing grounds. A KDE surface was created using a $10 \mathrm{~km}$ bandwidth, and resulting densities were estimated onto an underlying raster grid with a $1 \mathrm{~km}$ cell resolution for all albatross and fisheries data. The $10 \mathrm{~km}$ bandwidth was chosen so as to be equal to the sum of the individual bandwidths for fisheries and albatross ranges (5 $\mathrm{km}$ bandwidth each), such that any possible interaction (i.e. overlap) between ranges would not be discarded, and to avoid spatial discontinuities near edges. Any albatross data falling outside of this area would thus not be proximal to the fisheries and as such not relevant for identifying areas of elevated bycatch risk. The fisheries areas encompassed almost all of the coastal areas out to the $2000 \mathrm{~m}$ bathymetric contour, excluding inland waters (i.e. east of Vancouver Island; Fig. 1). 


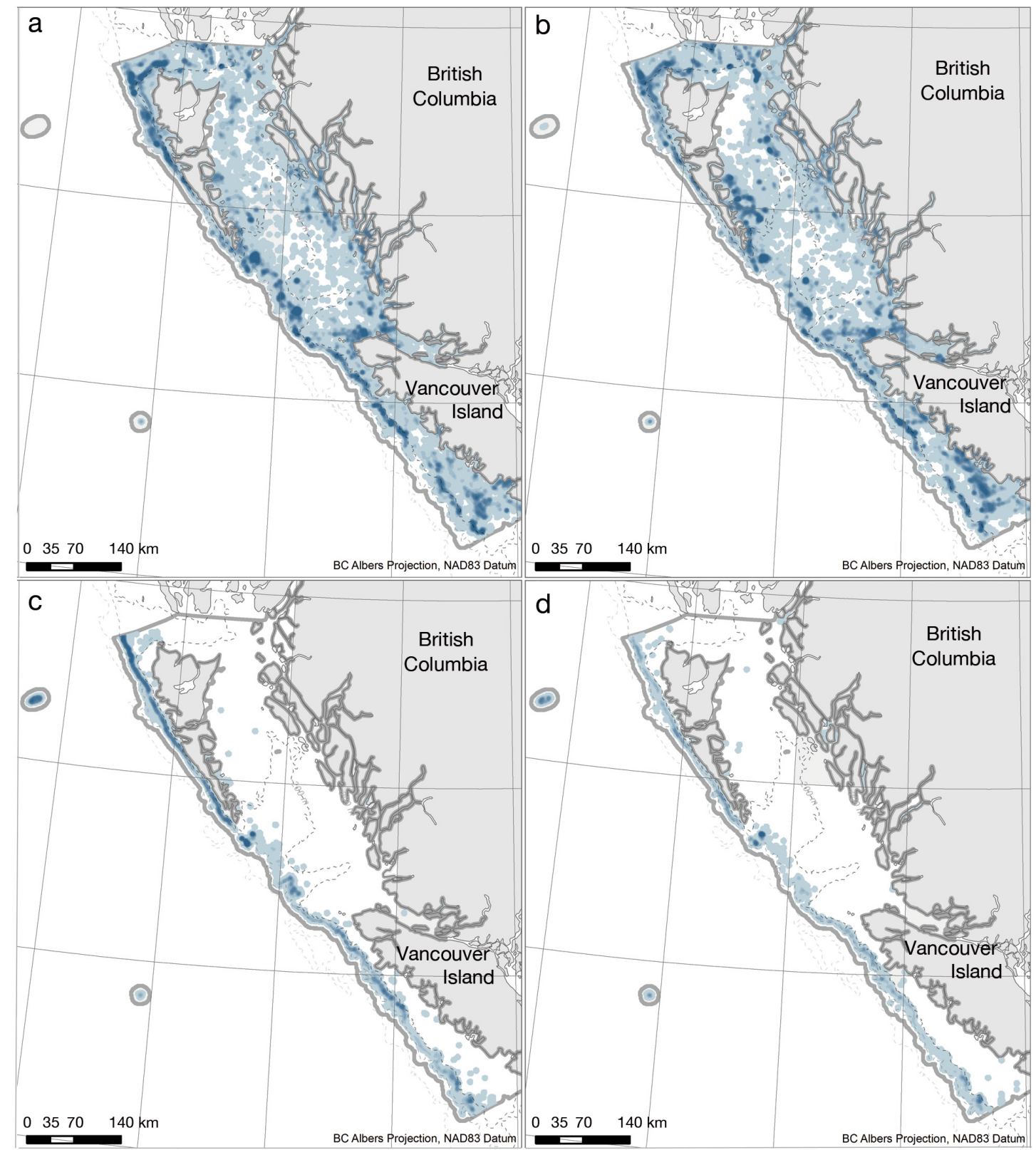

Fig. 3. Distribution of commercial longline fishing effort in albatross (a) breeding and (b) non-breeding seasons and commercial trap fishing effort in (c) breeding and (d) non-breeding seasons in the study area (outlined in grey)

The $95 \%$ volume contour of the combined albatross and fisheries densities was extracted to remove areas of low potential interaction. The final step was to intersect this vector polygon data with the study area defined based on previously identified criteria (i.e. within $2000 \mathrm{~m}$ bathymetric contour in the EEZ, with inland water areas excluded). This process resulted in a final operational study area that included relevant areas for identifying potential overlap between albatross survey observations and fishing event information (see Fig. 1). The total study area size was approximately $123000 \mathrm{~km}^{2}$.

The most important parameter in the estimation of kernel surfaces, the kernel bandwidth, which nominally determines the maximum distance for smoothing, was set to $5 \mathrm{~km}$ for both albatross and fisheries data. While this distance surely underestimates the region of influence for albatrosses and is smaller than bandwidths used in other studies (e.g. Wood et al. 2000), we opted for a spatially conservative bandwidth (i.e. under-smoothing) so as to limit going be- 
yond the data and focusing on localized potential interaction locations. This was an important parameterization given the biased sampling of the survey data and the management implications of identifying potential interactions between highly used areas by albatrosses and fisheries. As well, due to the highly spatially autocorrelated nature of both datasets and relatively long time period over which albatross observations were recorded, bandwidth selection aimed to limit spatial smoothing in favor of reducing bias (Fieberg 2007). A weight for each sighting observation was included in the KDE based on the density of birds observed over the transect. A $95 \%$ volume threshold was used to aggregate the density surfaces into discrete range polygons.

Due to the non-systematic sampling for the albatross database, a correction factor was applied to densities to account for survey effort. Adjusting observational data for variable sampling effort can take a variety of forms. In marine environments, the number of observations per unit area within the study domain can be used to represent overall survey effort in each location (e.g. Rechsteiner et al. 2013). For data used in this study, observers were generally highly skilled with years of experience; as such, all albatross observations were treated equally at each location (i.e. grid cell). Precisely how to use survey effort estimates to weigh observational data depends on the objective of analysis. Continuously dividing sightings density per unit of study effort (i.e. no. of sightings per no. of surveys) can be sensitive to anomalous values resulting from infrequently surveyed areas (i.e. visiting an area once and observing a bird would be $100 \%$, whereas visiting an area 70 times and observing 35 times would be $50 \%$ ). As such, we conservatively controlled for survey effort by aggregating survey effort into 3 groups: high survey effort, moderate survey effort, and low survey effort. Densities (counts per unit area) were corrected for survey effort after applying a correction factor separately for each survey effort grouping. For observations located within the upper third quantile of the survey effort (i.e. the most heavily surveyed areas), the correction factor was set to 2 ; locations in the middle third and lower third were set to 1.5 and 1.0, respectively. These values were chosen so that low effort densities would remain unchanged and are in line with more typical effort corrections that are normalized between zero and 1 . The correction factor was used to divide each density value, thereby lowering densities in heavily sampled areas. A sensitivity analysis of these correction values performed on a subset of the study area revealed the results were robust to small changes in these values.

\subsection{Albatross-fisheries potential interaction analysis}

To examine the spatial relationship between fishing effort and albatross distributions and densities over the breeding and non-breeding seasons, we focused on identifying potential areas of elevated risk of bycatch, formalized here as the degree of overlap in space and time (i.e. the breeding and nonbreeding seasons) with fishing effort (e.g. Jiménez et al. 2012). Because we were reliant on fairly long-term data series, our aim was not to identify specific instances of interaction and/or bycatch but rather to characterize the geographic and seasonal contours of potential interaction (a proxy for bycatch risk) in the study area. Additional albatross information is needed before determination of interannual and/or species-specific spatial interactions with commercial fisheries in Canada's Pacific coast waters is possible.

Quantifying the degree of potential interaction between 2 point patterns can be assessed in a number of ways (Fieberg \& Kochanny 2005). The albatross distribution and density data were obtained from a mixture of research designs. Additionally, spatial uncertainty existed in the identified locations that, even when aggregated, can manifest when observations are near edges of aggregation units (e.g. binning data). The distribution and abundance of North Pacific albatrosses are influenced by local, regional, and basin-wide oceanographic and atmospheric variability, operating at a range of time scales (e.g. Hyrenbach et al. 2002, Suryan et al. 2008, Conners et al. 2015, Santora \& Sydeman 2015, Thorne et al. 2015, 2016, Michael et al. 2016, Studwell et al. 2017, Wren et al. 2019). Further, their distributions are also likely influenced by the location and timing of fisheries operating across the North Pacific Ocean (e.g. Gould et al. 1998, Fernandez et al. 2001, Piatt et al. 2006). For the purposes of this study, the pattern of albatross sightings is considered to be random realizations of the spatial processes governing their distribution. As the albatross database covered a period of $28 \mathrm{yr}$, the aggregation of the data by bins represents an estimate of overall albatross distribution and density. Conversely, the fishing effort data encompassed a shorter time frame $(6.5 \mathrm{yr})$ but were spatially exhaustive in nature (i.e. excluding a small number of incomplete or missing records, almost all commercial fishing events are recorded in each year). We therefore examined the interaction between their joint densities to identify areas of potential interaction, which may be important proxies of bycatch risk. 
To investigate the highest density overlaps, we computed the product of the albatross and fisheries density surfaces and extracted the $50 \%$ volume contour as a vector polygon, which is typically used to denote core areas in home range studies (Laver \& Kelly 2008). These potential interaction hotspots were then mapped and compared across the albatross breeding and non-breeding seasons and by fisheries gear type. The spatial distribution of potential interaction hotspots was examined for qualitative spatial patterns (e.g. location and clustering).

\subsection{Indices of albatross-fisheries potential interaction analysis}

Overlap statistics for the density surfaces and range polygons were used to classify risk, as proxied by spatial potential interaction. For each season (i.e. breeding and non-breeding), 3 different overlap indices were used to examine the spatial potential interaction between fisheries and albatrosses (see Fieberg \& Kochanny 2005 for more details). The simplest measure is the proportion of the albatross range polygons (i.e. cells within the $95 \%$ volume contour) that overlapped with the range polygons of a fishing effort type (e.g. longline fishery), defined as:

$$
R_{a, f}=R_{a \cap f} / R_{a}
$$

where $R_{a_{1} f}$ is the proportion of albatross range $\left(R_{a}\right)$ that overlaps with fishing effort range $\left(R_{f}\right)$. As such, this measure is directional, in that $R_{a, f} \neq R_{f, a}$ Because we were interested in risk to albatrosses (and not to fisheries), only results related to albatross range (i.e. $R_{a}$ for the denominators) were considered (i.e. assuming $R_{f}$ is not itself representative of albatross distributions). One issue with $R_{a_{t} f}$ is that it is based on range overlap only and does not consider the density of albatrosses.

A second method incorporated the probability of events via the utilization distribution (i.e. the kernel surface enumerated over a spatial grid of discrete cells) to determine the probability of albatrosses interacting with fisheries (PR), defined as:

$$
\mathrm{PR}_{a, f}=\sum_{i=1}^{n_{f}} P\left(a_{i}\right)
$$

where $n_{f}$ is the grid cells found within the range polygon for fishing effort, and $P\left(a_{i}\right)$ is the probability of albatrosses in grid cell $i$ derived from the utilization distribution of albatrosses. $\mathrm{PR}_{a, f}$ can be interpreted as the probability of finding albatrosses within the range of fisheries $f$.
Finally, our third measure of overlap of the utilization distributions of albatrosses and fisheries (longline and trap) uses the volume of intersection (VI) statistic in the discrete case, VI is derived as follows:

$$
\mathrm{VI}_{a_{1} f}=\sum_{i=1}^{n_{\text {an } f}} \operatorname{Min}\left(P\left(a_{i}\right), P\left(f_{i}\right)\right)
$$

where $n_{a n f}$ is the set of grid cells common to range polygons for both albatrosses and fisheries, and $P\left(f_{i}\right)$ is the probability of fishing activity in grid cell $i$. The VI statistic has a value of zero when 2 ranges do not overlap and a value of 1 when they are identical. In this way, VI can be seen as a non-directional extension of PR.

\subsection{Albatross bycatch incidents for confirming potential interaction hotspot analysis}

The albatross-fisheries potential interaction hotspots derived from the product of the kernel surfaces were compared to the observed bycatch incidents through visual inspection and mapping. Additionally, the distance from each bycatch incident to the nearest potential interaction hotspot (hotspot edge) was determined and the distribution of distances examined for distance decay effects. If bycatch incidents were located within a hotspot, the distance was denoted as zero. Finally, the percentage and density of bycatch incidents located within potential interaction hotspots were evaluated, and hotspots were ranked based on bycatch density. To explore accuracy, the bycatch incidents accurately estimated by potential interaction hotspots and those that were not were compared to the underlying seabird survey effort (average density of ship survey points) using a 1-tailed Mann-Whitney $U$-test and a Welch 2-sample $t$-test to determine if those events that were not correctly estimated were found in locations with lower overall survey effort. Using the short-tailed albatross sightings, an evaluation of co-occurrence and proximity of short-tailed albatross sightings with albatross-longline fisheries potential interaction hotspots was also undertaken.

\section{RESULTS}

\subsection{Albatross sightings and fishing events}

Within the study area, there were 18577 transects (25 $202 \mathrm{~km}$ ) in the combined (1982-2010) albatross survey effort database, with 11092 (14133 km) oc- 
curring in the breeding season and $7485(11069 \mathrm{~km})$ in the non-breeding season (Table 1, Fig. 2). Of those, 1 or more albatrosses were observed in 1288 transects $(2003 \mathrm{~km})$, with just over $60 \%$ occurring in the breeding season (Table 1). The temporal distribution of albatross sightings relative to survey effort indicates peak relative abundance in September, followed by May and June, with relatively lower abundance from October through April (Fig. 4a).

There were $121138(101770 \mathrm{~km})$ fishing events (2006-2012) in the study area (Table 1, Fig. 3), of which $88.6 \%$ involved longline gear and $11.4 \%$ involved trap gear (Table 1). The seasonal distribution of longline fishing events was unimodal, with an elevated number of events from March to October and peaking in summer (Fig. 4b). Relative to the breeding schedule of albatrosses, longline fishing effort was equally divided, with $50.6 \%$ of longline fishing midpoints occurring during the breeding season and $49.5 \%$ during the non-breeding season (Table 1). In contrast, for trap fishing, the majority ( $>73 \%$ ) of trap fishing events occurred during the albatross breeding season (Table 1, Fig. 4b).

\subsection{Albatross-longline fisheries potential interactions}

Potential interaction hotspots between longline fisheries and albatrosses were similar in both seasons, being generally concentrated along the continental shelf break and outer shelf regions (Fig. 5a,b). Four regions of high bycatch risk were identified: (1) western Dixon Entrance; (2) western Queen Charlotte Sound, particularly southeast of Cape St. James, Haida Gwaii, and north of the Scott Islands group; (3)

Table 1. Summary of albatross survey effort (1982-2010) and longline and trap fisheries efforts (no. of fishing event midpoints and kilometers fished from start to finish; 2006-2012) based on average albatross breeding and nonbreeding seasons (breeding: Dec 1-Jun 30; non-breeding: Jul 1-Nov 30) in the study area

\begin{tabular}{|c|c|c|c|c|c|c|}
\hline & \multicolumn{2}{|c|}{ Breeding season } & \multicolumn{4}{|c|}{ Non-breeding season $\longrightarrow$ Total -} \\
\hline & $\begin{array}{l}\text { No. of } \\
\text { midpoints }\end{array}$ & $\begin{array}{l}\text { Effort } \\
(\mathrm{km})\end{array}$ & $\begin{array}{c}\text { No. of } \\
\text { midpoints }\end{array}$ & $\begin{array}{l}\text { Effort } \\
(\mathrm{km})\end{array}$ & $\begin{array}{l}\text { No. of } \\
\text { midpoints }\end{array}$ & $\begin{array}{l}\text { Effort } \\
(\mathrm{km})\end{array}$ \\
\hline \multicolumn{7}{|c|}{ Albatross survey effort } \\
\hline Albatrosses present & 774 & 1260 & 514 & 743 & 1288 & 2003 \\
\hline Albatrosses absent & 10318 & 12873 & 6971 & 10326 & 17289 & 23199 \\
\hline Total survey effort & 11092 & 14133 & 7485 & 11069 & 18577 & 25202 \\
\hline \multicolumn{7}{|l|}{ Fishing effort } \\
\hline Longline & 54275 & 36690 & 53094 & 32331 & 107369 & 69021 \\
\hline Trap & 10157 & 25091 & 3612 & 7561 & 13769 & 32652 \\
\hline Total fishing effort & 64432 & 61782 & 56706 & 39893 & 121138 & 101675 \\
\hline
\end{tabular}

west of Nootka Sound, central Vancouver Island, and ${ }_{i}(4)$ southwest of Vancouver Island (see Fig. 1 for locations; Fig. 5a,b).

There was a higher potential for albatross-longline fisheries interactions during the breeding season than during the non-breeding season, according to multiple overlap indices. The proportion of range overlap $\left(R_{a, f}\right)$ indicated a higher magnitude of potential interaction occurring during the breeding season (75 vs. $65 \%$ ). The probability of interaction between albatrosses and fisheries (PR) was higher during the breeding season ( 0.45 vs. 0.28$)$. The volume of intersection statistic (VI) was greater during the breeding season ( 0.31 vs. 0.25 ; Table 2 ). Finally, the total surface area of the potential interaction hotspots was slightly larger during the breeding season $\left(2794 \mathrm{~km}^{2}\right)$ than during the non-breeding season $\left(2514 \mathrm{~km}^{2}\right.$; Table 2).

\subsection{Albatross-trap fisheries potential interactions}

Overall, there were far fewer trap fisheries than longline fisheries occurring in the study area (Table 1). Spatially, trap fisheries largely occurred along the shelf break during the albatross breeding and nonbreeding seasons (Fig. 3c,d). Unlike longline fisheries effort, which occurred relatively evenly over the breeding and non-breeding seasons while demonstrating strong monthly patterns, trap fisheries effort was more constant on a monthly basis but with lower effort during the albatross non-breeding season (Table 1, Fig. 4b,c).

Estimated potential interaction hotspots between trap fisheries and albatrosses were concentrated along the shelf break, particularly adjacent to Haida Gwaii during the breeding season (Fig. 5c,d). During the non-breeding season, hotspot potential interactions were located over Bowie Seamount, south of Cape St. James, Haida Gwaii, and west of Barkley Sound (see Fig. 1 for locations; Fig. 5c,d). Similar to longline fisheries, overlap indices were higher for trap fisheries in the breeding season, and the potential interaction hotspot area was also substantially larger (2579 vs. $1625 \mathrm{~km}^{2}$; Table 2).

\subsection{Albatross bycatch incidents}

Over the 9 yr of fisheries bycatch information examined in this study (2006-2014), 189 albatross bycatch in- 

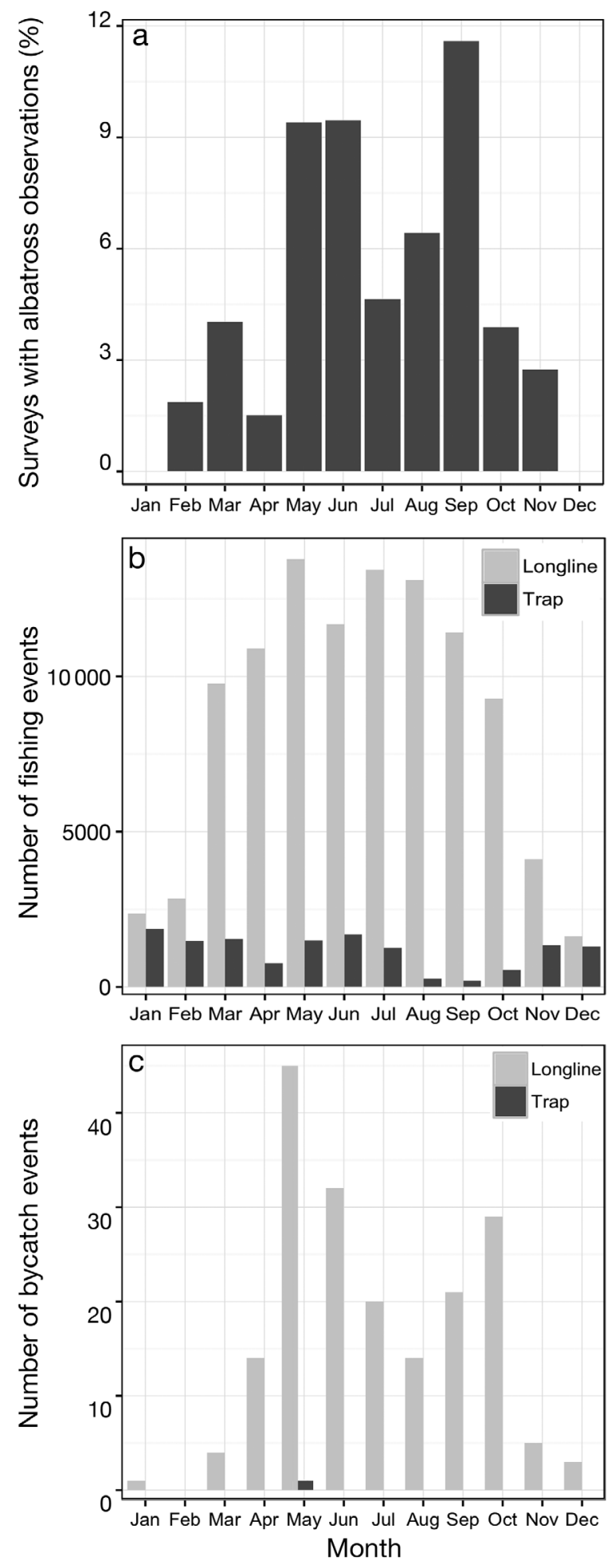

Fig. 4. Annual distribution of (a) survey midpoints with albatrosses present (1982-2010), (b) commercial longline and trap fisheries event midpoints (2006-2012), and (c) number of albatrosses caught on longlines and in traps (2006-2014) by month. Analyses were based on average albatross breeding and non-breeding seasons (breeding: Dec 1-Jun 30; non-breeding: Jul 1-Nov 30) cidents were reported, with 100 occurring during the breeding season and 89 during the non-breeding season (Fig. 4c). With the exception of a single reported bycatch incident in a trap, all reported albatrosses were captured in longline fisheries (Fig. 4c). Of the longline albatross bycatch incidents, 161 $(85.2 \%)$ involved the capture of a single albatross, 19 $(10.1 \%)$ involved 2 birds, $4(2.1 \%)$ involved 3 birds, and $5(2.6 \%)$ involved greater than 3 birds. The highest reported number of albatrosses taken in a single fishing event was 7.

Seasonally, a bimodal distribution of albatrosslongline fisheries bycatch incidents is noticeable, with May, June, and October having the highest bycatch levels (Fig. 4c). Monthly albatross bycatch incidents and monthly longline fisheries events were significantly correlated (Spearman's rank correlation coefficient $=0.774, p=0.003$ ). Given that only 1 albatross-trap fisheries bycatch incident was reported, we map the location of this event (Fig. 6) and generate overlap indices but undertake no further analysis of trap fisheries.

Using a visual assessment, the distribution of albatross-longline fisheries bycatch incidents aligned with the locations of the longline potential interaction hotspots, with reported bycatch incidents generally concentrated along the continental shelf break (Fig. 6). In terms of the percentage of bycatch incidents falling within longline fisheries potential interaction hotspots, this was found to be $38 \%$ in the breeding season and $33 \%$ in the non-breeding season (Table 3). Although relatively low, when examined in terms of distance decay, strong associations were evident between longline fisheries potential interaction hotspots and bycatch incidents in both seasons (Fig. 7). Approximately $80 \%$ of reported incidents occurred within $10 \mathrm{~km}$ of a longline fisheries hotspot during the breeding season, while roughly $50 \%$ of the bycatch incidents occurred within $10 \mathrm{~km}$ during the non-breeding season (Fig. 7).

In terms of observed bycatch incident density occurring within potential interaction hotspots, longline potential interaction hotspots had the highest density of observed bycatch incidents, with slightly elevated bycatch occurring during the breeding season (1.36 albatrosses $100 \mathrm{~km}^{-2}$ ) in comparison to the non-breeding season (1.15 albatrosses $100 \mathrm{~km}^{-2}$; Table 3). Defining bycatch incidents within the longline potential interaction hotspot as correct predictions, we compared the normalized albatross survey effort for these locations with those not correctly predicted (i.e. 
Table 2. Spatial overlap indices for albatrosses and commercial longline and trap fisheries. See Section 2.6 for additional details on overlap indices and hotspot area calculation

\begin{tabular}{|c|c|c|c|c|}
\hline \multirow[t]{2}{*}{ Overlap index } & \multicolumn{2}{|c|}{ Breeding season } & \multicolumn{2}{|c|}{ Non-breeding season } \\
\hline & Longline & Trap & Longline & Trap \\
\hline Proportion of range overlap & p $\quad 0.75$ & 0.56 & 0.65 & 0.44 \\
\hline Probability of interaction & 0.45 & 0.73 & 0.28 & 0.61 \\
\hline Volume of intersection & 0.31 & 0.37 & 0.25 & 0.33 \\
\hline Hotspot area $\left(\mathrm{km}^{2}\right)$ & 2794 & 2579 & 2514 & 1625 \\
\hline
\end{tabular}

located outside of potential interaction hotspots) as a means of assessing the unevenness of survey effort within and outside of hotspots. The normalized albatross survey effort for correctly predicted bycatch incidents was higher (mean events $=0.11 \pm$ 0.01) than for those events found outside of the longline hotspots (mean events $=0.07 \pm$ 0.013); these differences were significant (Welch 2-sample $t$-test; $t=-2.171, \mathrm{p}=$
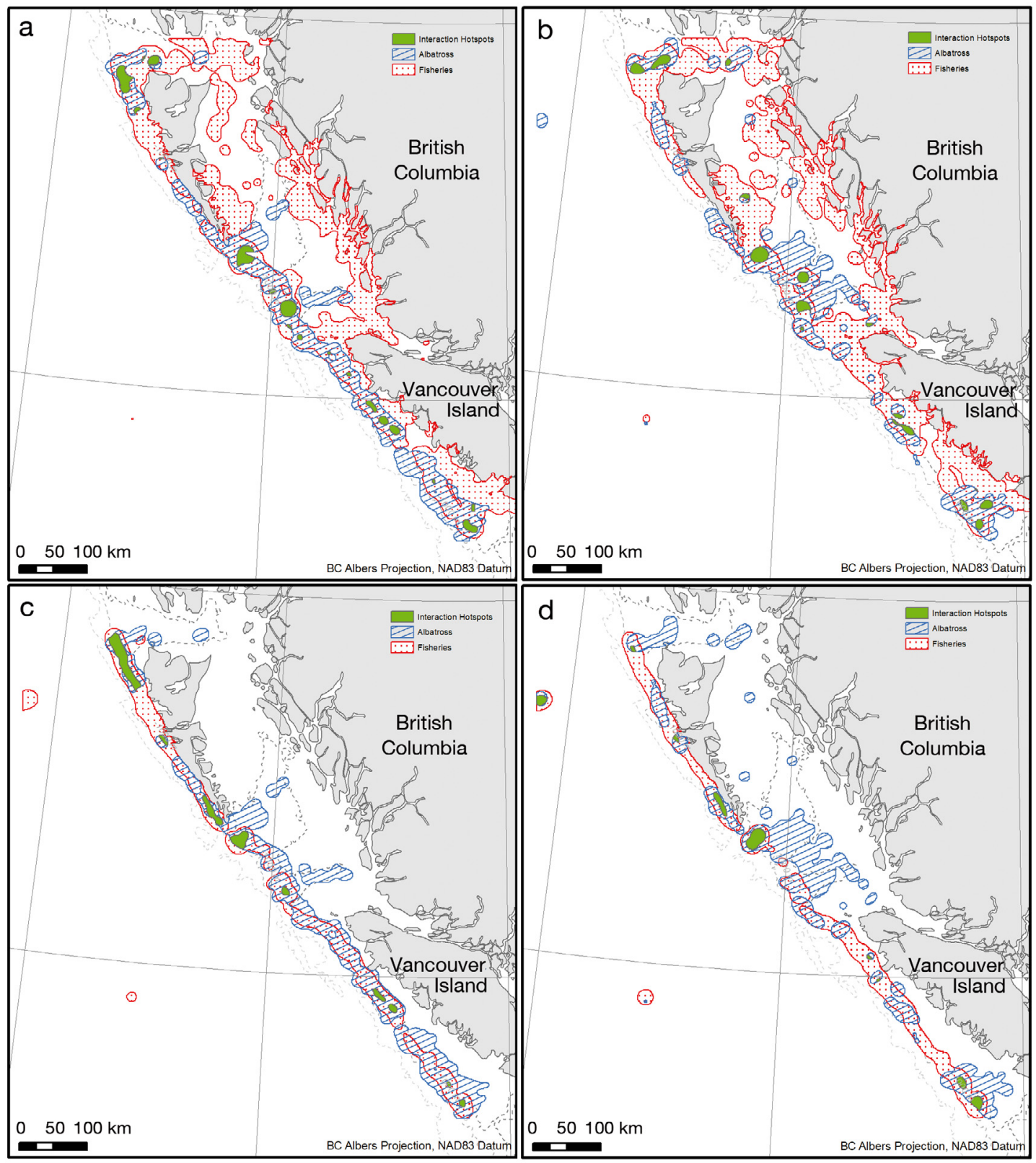

Fig. 5. Spatial overlap and potential interaction hotspots for $(a, b)$ albatrosses (1982-2010) and commercial longline fisheries (2006-2012) in (a) breeding and (b) non-breeding seasons, and for (c,d) albatrosses and commercial trap fisheries (2006-2012) in (c) breeding and (d) non-breeding seasons 


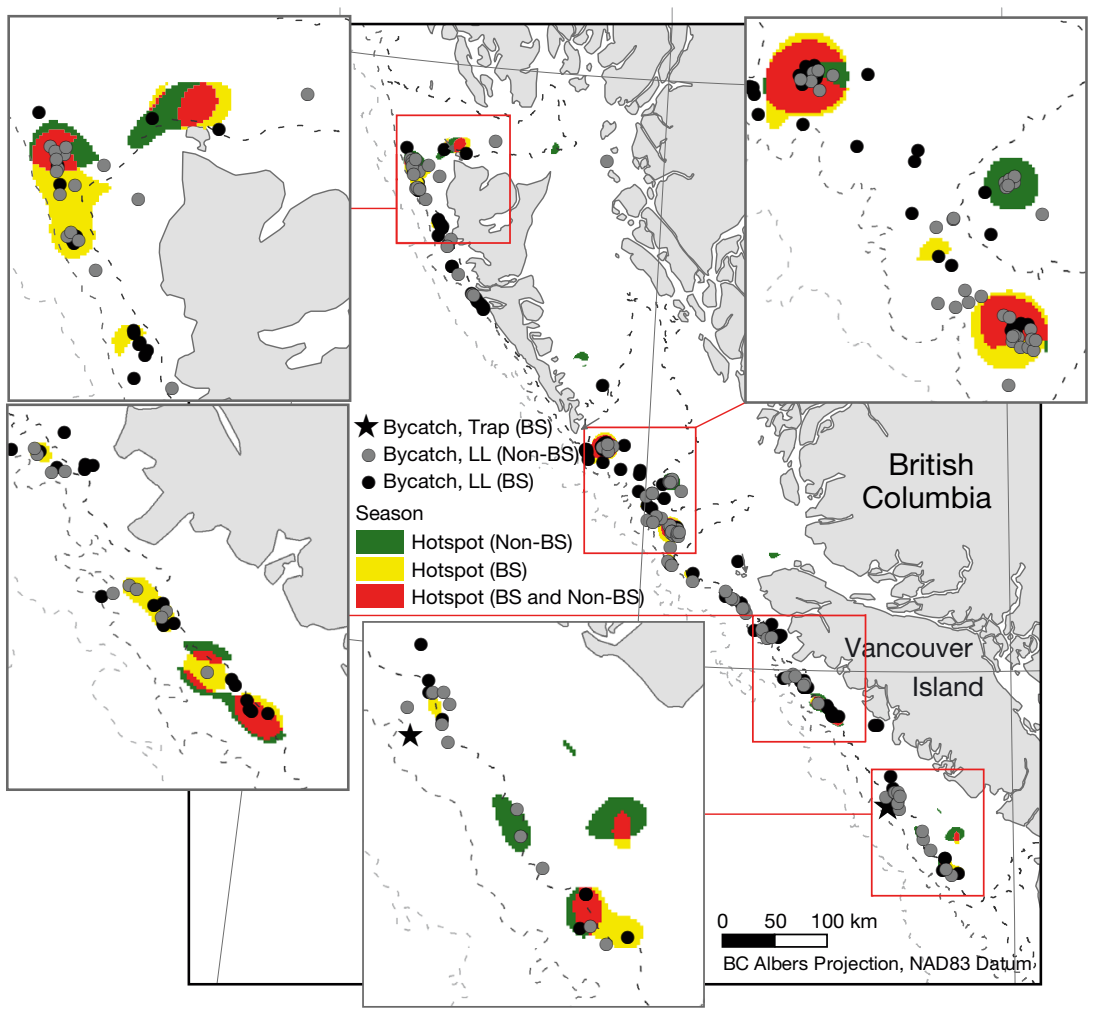

Fig. 6. Estimated albatross-longline (LL) fisheries potential interaction hotspots and observed albatross bycatch incidents (breeding season [BS]: Dec 1-Jun 30, black circles; non-breeding season [Non-BS]: Jul 1-Nov 30, grey circles) in the study area. Star represents the only reported bycatch incident in trap fisheries (BS)

Table 3. Percent and number $\left(100 \mathrm{~km}^{-2}\right)$ of observed albatross bycatch incidents occurring within estimated potential interaction hotspot and range polygons during albatross breeding and non-breeding seasons (breeding: Dec 1-Jun 30; non-breeding: Jul 1-Nov 30) in the study area. Range polygons were generated from albatross sightings and fishing effort using kernel density estimation. Hotspots represent areas of estimated spatial potential interaction between albatross and fishing range polygons. For additional information, see Section 2

\begin{tabular}{|c|c|c|c|c|}
\hline \multirow[t]{2}{*}{ Hotspot or range type } & \multicolumn{2}{|c|}{ Breeding season } & \multicolumn{2}{|c|}{ Non-breeding season } \\
\hline & Percent & $\begin{array}{l}\text { No. of events } \\
100 \mathrm{~km}^{-2}\end{array}$ & Percent & $\begin{array}{l}\text { No. of events } \\
100 \mathrm{~km}^{-2}\end{array}$ \\
\hline Albatross range & 74.8 & 0.27 & 54.0 & 0.19 \\
\hline Longline range & 97.0 & 0.16 & 98.9 & 0.14 \\
\hline Trap range & 84.8 & 0.44 & 80.9 & 0.37 \\
\hline $\begin{array}{l}\text { Albatross-longline potential } \\
\text { interaction hotspot }\end{array}$ & 38.4 & 1.36 & 32.6 & 1.15 \\
\hline $\begin{array}{l}\text { Albatross-trap potential } \\
\text { interaction hotspot }\end{array}$ & 28.2 & 1.09 & 10.1 & 0.55 \\
\hline
\end{tabular}

0.016), indicating that there was lower survey effort associated with bycatch incidents located outside of the longline potential interaction hotspots.

\subsection{Short-tailed albatross occurrences}

As a final evaluation, we examined the co-occurrence and proximity of short-tailed albatross sightings with the albatross-longline fisheries potential interaction hotspots. The majority of short-tailed albatross sightings occurred along the continental shelf break (Fig. 8). Of 60 sightings (of 1 or more albatrosses per sighting) in the study area, 36 (60.0\%) occurred within $10 \mathrm{~km}$ of an albatross-longline hotspot, and 56 (93.0\%) sightings occurred within $30 \mathrm{~km}$.

\section{DISCUSSION}

The distributions of albatrosses and commercial longline and trap fisheries substantially overlap in Canada's coastal waters. Hotspots of potential interaction, meaning areas where high densities of albatrosses likely co-occurred with high densities of longline and trap fishing events, were largely concentrated along the continental shelf break, although hotspot locations differed slightly by albatross breeding schedule. Overlap, as estimated using several indices, was substantial for both longline and trap fisheries. As an example, a high proportion of the albatross and longline fishing ranges were estimated to overlap in the breeding season $(75 \%)$, with nearly $2800 \mathrm{~km}^{2}$ of surface water estimated to represent hotspots of potential interaction.

Hotspots of albatross-fisheries potential interactions represent an indirect proxy for risk but may not necessarily reflect actual bycatch risk. The reported bycatch incident records provided a unique opportunity to evaluate hotspots as locations of elevated bycatch risk, in addition to directly examining patterns of bycatch incident locations. Trap fisheries only reported 1 albatross bycatch incident, suggesting that these fisheries are responsible for very low albatross mortalities despite substantial spatial overlap between trap fish- 


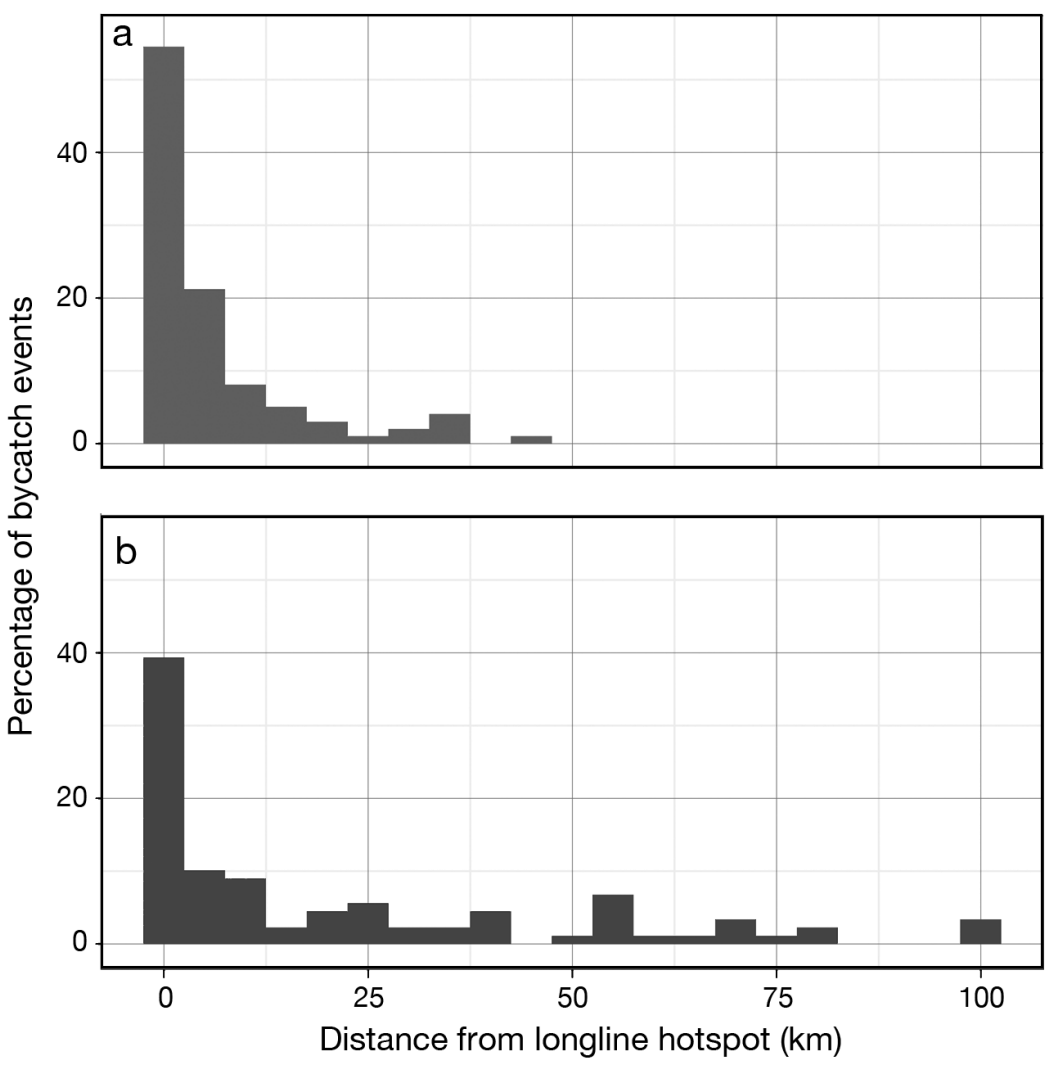

Fig. 7. Percentage of total observed albatross bycatch incidents with distance $(\mathrm{km})$ to nearest commercial longline fisheries potential interaction hotspots during albatross (a) breeding and (b) non-breeding seasons

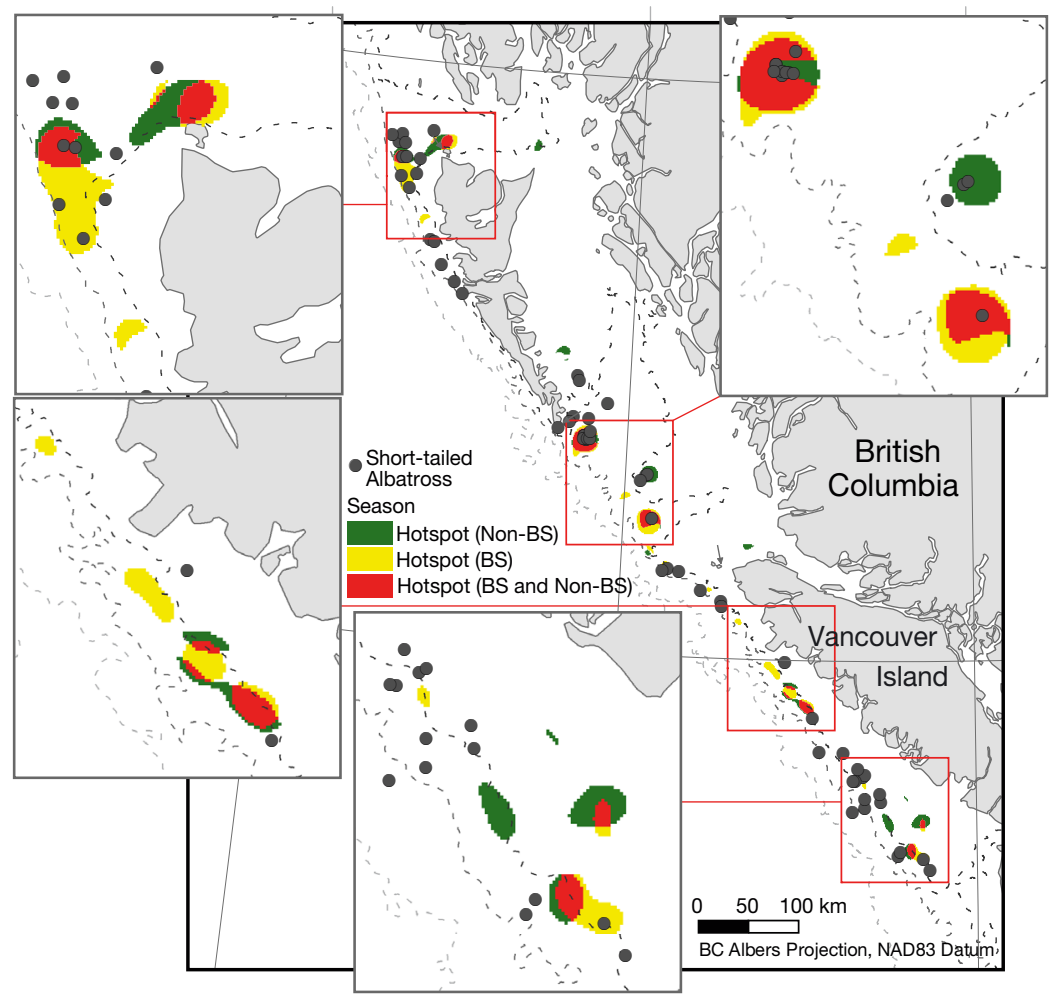

eries and albatrosses. Reduced bycatch incidence despite similar estimates of potential interaction suggests that the actual interaction is lower for trap fisheries than for longline fisheries or that albatrosses are less sensitive (sensu Zacharias \& Gregr 2005) to interactions with trap fisheries. Previously, trap fisheries mortality was not well understood in Canada's Pacific coast waters (e.g. Smith \& Morgan 2005). In contrast to the trap fisheries, over $80 \%$ of recorded bycatch incidents occurred within $10 \mathrm{~km}$ of the albatross-longline fisheries hotspot locations, providing evidence that albatross-longline potential interaction hotspots and adjacent areas represent actual areas of elevated bycatch risk. The majority of reported bycatch incidents were concentrated along the shelf break and occurred in breeding and non-breeding seasons.

Bycatch risk depends on more than just spatial co-occurrence between albatrosses and fishery type. Vessel operation, including fishing target, technique, nature of bycatch discards, weather, diversity of seabirds in the vicinity, use of seabird avoidance gear, and availability of alternative food sources, may influence seabirdfisheries interactions (e.g. Weimerskirch et al. 2000, Dietrich 2003, Sullivan 2004, Abraham et al. 2009, Jiménez et al. 2009, Pierre et al. 2012); these factors were not explored as part of our analysis. Further, although survey information was dominated by observations of black-footed albatrosses, short-tailed and Laysan albatrosses also occur in the study region; interspecific differences in bycatch vulnerability, whether related to differences in spatiotemporal overlap with commercial fisheries (e.g. Fischer

Fig. 8. Albatross-longline fisheries potential interaction hotspots and sightings of shorttailed albatross Phoebastria albatrus (19902018 ) in the study area. Locations of shorttailed albatrosses represent unique observations of 1 or more individuals 
et al. 2009) or behaviour around vessels, are likely. To illustrate that, Granadeiro et al. (2011) noted that despite efforts to document the degree of overlap between susceptible seabirds and fishing fleets, individual interactions with fishing vessels remain poorly known, including whether individuals specialize in ship following, the proportion that does so, and the amount of time spent in association with vessels. Although the fisheries information relied on in this study was considered complete, with sufficient detail to examine on an interannual basis, additional albatross information is needed before determination of interannual and/or species-specific interactions with commercial fisheries in Canada's Pacific coast waters is possible.

Of the 3 species present in Canada's Pacific coast waters, existing evidence suggests low overlap of Laysan albatrosses with the continental shelf- and shelf break-focused commercial longline and trap fisheries examined in this study, as the species tends to occur farther offshore (Fischer et al. 2009, Kenyon et al. 2009). Similarly, in adjacent US waters, Guy et al. (2013) found that Laysan albatrosses primarily occur offshore, beyond the shelf- and shelf breakfocused groundfish and shrimp fishing effort summarized in their study. However, this species is frequently caught in some fisheries (e.g. Alaska sablefish longline fishery; Melvin et al. 2003), is potentially vulnerable to longline fisheries off the west coast of the continental USA (Gladics et al. 2017), and has bycatch conservation concerns throughout a substantial proportion of its range (e.g. Fischer et al. 2009). Consequently, further investigation of Laysan albatross bycatch in Canada's Pacific coast waters is warranted.

Black-footed albatrosses are wide ranging throughout the Pacific Ocean, and distributions in coastal waters tend to be concentrated in the slope and shelf break regions (Fischer et al. 2009, Kenyon et al. 2009, Fox et al. 2017). The population is comprised of immatures, non-breeders, and breeding birds commuting from Hawaii (e.g. Hyrenbach et al. 2006, Kappes et al. 2010, Gutowsky et al. 2015). The overlap between black-footed albatrosses and commercial fisheries in the North Pacific Ocean has previously been documented over broad spatial scales (e.g. Fischer et al. 2009). Overlap between longline fisheries and black-footed albatrosses has been reported previously in Canadian Pacific waters (e.g. Wiese \& Smith 2003), and our study provides finer spatial scale cooccurrence of groundfish fisheries and black-footed albatrosses, in addition to the identification of hotspots of potential interaction located along the shelf break during breeding and non-breeding seasons. Although identification issues exist, black-footed albatrosses likely represent the majority of albatrosses reported as bycatch in our study. First, the species dominated survey sightings in our study and are the most abundant albatross in Canada's Pacific waters (e.g. Kenyon et al. 2009, Fox et al. 2017). Second, the species distribution is known to be concentrated near the shelf break and slope (e.g. Kenyon et al. 2009, Fox et al. 2017). Third, the species represents the most frequently reported seabird species in the bycatch of British Columbia's longline fisheries, with potentially hundreds (or more) of black-footed albatrosses caught in longline fisheries each year (Smith \& Morgan 2005). Listed as special concern under Canada's Species at Risk Act (SARA) and as Near Threatened by the IUCN, bycatch issues remain a leading conservation concern for blackfooted albatrosses (ECCC 2017, Bakker et al. 2018).

Species-level identification of bycatch incidents, particularly for species at risk, is a crucial and poorly understood knowledge component (ECCC 2017). The short-tailed albatross is listed as threatened under SARA and as Vulnerable by the IUCN, and the recovery strategy for this species lists the extent of spatial and temporal overlap of short-tailed albatrosses with commercial longline fisheries as an important information gap (Environment Canada 2008). Reported in commercial fisheries in Alaska, Oregon, Russia, and Japan (Good et al. 2015), no short-tailed albatrosses have yet been reported as bycatch in Canadian commercial fisheries, although this may be largely (or entirely) due to a lack of species-level identification and/or under-reporting of bycatch incidents as opposed to a documented absence of shorttailed albatross bycatch. While the distribution of short-tailed albatrosses in Canadian waters is poorly described, with less than 100 individuals documented (COSEWIC 2013), this study reaffirms existing knowledge of short-tailed albatross species associations with shelf break and slope regions in British Columbia's waters and throughout the North Pacific (e.g. Suryan et al. 2007, Orben et al. 2018).

In Canada's Pacific coast waters, short-tailed albatrosses, particularly immatures, overlap with shelf break- and slope-associated commercial fisheries, including longline fisheries; in this study, $60 \%$ of short-tailed albatross sightings within the study area occurred within $10 \mathrm{~km}$ of albatross-longline hotspots and $93 \%$ within $30 \mathrm{~km}$. Using information from tagged birds, O'Connor (2013) similarly found associations between longline vessels and short-tailed albatross high-use areas. However, short-tailed alba- 
tross bycatch incidents were also found to occur outside of short-tailed albatross high-use and vessel association areas (O'Connor 2013). With a global population estimate of 7365 individuals, based on a deterministic model using an annual growth rate of $8.9 \%$ (USFWS 2020), even low bycatch mortalities could impede short-tailed albatross population recovery. As the population of short-tailed albatrosses recovers, it is anticipated that the number of individuals using British Columbian waters will rise (COSEWIC 2013), and consequently bycatch incidents may also increase. Our results suggest that short-tailed albatross bycatch has the potential to occur, and possibly increase, in the future; we recommend that targeted research should be a high priority.

\section{CONCLUSIONS}

Building on previous research that identified conservation concerns regarding black-footed albatross bycatch in longline fisheries in British Columbia (Smith \& Morgan 2005), this study provides evidence of extensive overlap between commercial groundfish fisheries and albatrosses, identifies hotspots of albatross-longline and trap fisheries potential interactions, and further confirms albatross-longline fisheries hotspots and adjacent waters as areas of elevated bycatch risk. Although this study provides no species-specific resolution, black-footed albatrosses are the most abundant albatross in British Columbia and likely represent much of the reported albatross bycatch in commercial longline fisheries. With a highly vulnerable population of short-tailed albatrosses, possible bycatch of this species remains a serious and poorly understood conservation issue in Canadian waters. Finally, given recent evidence of low compliance in the use of mandatory paired deterrent devices in commercial longline fisheries (D. De Gagne, Fisheries and Oceans Canada, pers. comm. August 2020), there is elevated conservation concern and need for greater understanding of how many albatrosses are being caught and where, when, and in which specific commercial fisheries they are being caught to direct further mitigation efforts to reduce bycatch.

Acknowledgements. The authors thank 3 anonymous reviewers for their contributions to the manuscript and acknowledge support and data provided by ECCC and Fisheries and Oceans Canada. We also acknowledge Dustin De Gagne from Fisheries and Oceans Canada for his contributions. The study was partially funded by the Canadian Wild- life Service branch of ECCC, which also supported K.H.M. and P.D.O. R.T. was supported by Fisheries and Oceans Canada. C.R. was supported by the Canadian Wildlife Service and Wilfrid Laurier University. C.H.F. was supported by Dalhousie University and the Canadian Wildlife Service. Albatross information and associated data products were also provided by C.H.F. and the Raincoast Conservation Foundation.

\section{LITERATURE CITED}

Abraham ER, Pierre JP, Middleton DAJ, Cleal J, Walker NA, Waugh SM (2009) Effectiveness of fish waste management strategies in reducing seabird attendance at a trawl vessel. Fish Res 95:210-219

Anderson ORJ, Small CJ, Croxall JP, Dunn EK, Sullivan BJ, Yates O, Black A (2011) Global seabird bycatch in longline fisheries. Endang Species Res 14:91-106

Anthony RG, Estes JA, Ricca MA, Miles AK, Forsman ED (2008) Bald eagles and sea otters in the Aleutian archipelago: indirect effects of trophic cascades. Ecology 89: 2725-2735

Arnold JM, Brault S, Croxall JP (2006) Albatross populations in peril: a population trajectory for black-browed albatrosses at South Georgia. Ecol Appl 16:419-432

Awkerman JA, Huyvaert KP, Mangel J, Shigueto JA, Anderson DJ (2006) Incidental and intentional catch threatens Galapagos waved albatross. Biol Conserv 133:483-489

Bakker VJ, Finkelstein ME, Doak DF, VanderWerf EA and others (2018) The albatross of assessing and managing risk for long-lived pelagic seabirds. Biol Conserv 217: 83-95

Bartle JA (1991) Incidental capture of seabirds in the New Zealand subantarctic squid trawl fishery, 1990. Bird Conserv Int 1:351-359

Brothers N, Duckworth AR, Safina C, Gilman EL (2010) Seabird bycatch in pelagic longline fisheries is grossly underestimated when using only haul data. PLOS ONE 5:e12491

* Campbell LM, Silver JJ, Gray NJ, Ranger S and others (2009) Co-management of sea turtle fisheries: biogeography versus geopolitics. Mar Policy 33:137-145

Collet J, Patrick SC, Weimerskirch H (2015) Albatrosses redirect flight towards vessels at the limit of their visual range. Mar Ecol Prog Ser 526:199-205

Conners MG, Hazen EL, Costa DP, Shaffer SA (2015) Shadowed by scale: subtle behavioral niche partitioning in two sympatric, tropical breeding albatross species. Mov Ecol 3:28

* Copello S, Pon JP, Favero M (2014) Spatial overlap of blackbrowed albatrosses with longline and trawl fisheries in the Patagonian Shelf during the non-breeding season. J Sea Res 89:44-51

COSEWIC (Committee on the Status of Endangered Wildlife in Canada) (2013) COSEWIC assessment and status report on the short-tailed albatross Phoebastria albatrus in Canada. COSEWIC, Ottawa. www.registrelep-sara registry.gc.ca/default_e.cfm

Croxall JP, Butchart SHM, Lascelles B, Stattersfield AJ, Sullivan B, Symes A, Taylor P (2012) Seabird conservation status, threats and priority actions: a global assessment. Bird Conserv Int 22:1-34

Dietrich KS (2003) Factors affecting seabird bycatch in Alaska longline fisheries. MSc thesis, University of Washington, Seattle, WA 
Domingo A, Jiménez S, Abreu M, Forselledo R, Yates O (2017) Effectiveness of tori line use to reduce seabird bycatch in pelagic longline fishing. PLOS ONE 12: e0184465

ECCC (Environment and Climate Change Canada) (2017) Management plan for the black-footed albatross (Phoebastria nigripes) in Canada. Species at Risk Act Management Plan Series. ECCC, Ottawa

Environment Canada (2008) Recovery strategy for the shorttailed albatross (Phoebastria albatrus) and the pinkfooted shearwater (Puffinus creatopus) in Canada. Species at Risk Act Recovery Strategy Series. Environment Canada, Ottawa

Fernandez P, Anderson DJ, Sievert PR, Huyvaert KP (2001) Foraging destinations of three low-latitude albatross (Phoebastria) species. J Zool (Lond) 254:391-404

* Fieberg J (2007) Kernel density estimators of home range: smoothing and the autocorrelation red herring. Ecology 88:1059-1066

Fieberg J, Kochanny CO (2005) Quantifying home-range overlap: the importance of the utilization distribution. J Wildl Manag 69:1346-1359

Fischer KN, Suryan RM, Roby DD, Balogh GR (2009) Postbreeding season distribution of black-footed and Laysan albatrosses satellite-tagged in Alaska: inter-specific differences in spatial overlap with North Pacific fisheries. Biol Conserv 142:751-760

Fisheries and Oceans Canada (2019) FN0253 - commercial - groundfish - seabird avoidance conditions of licence. Fisheries and Oceans Operations Centre, sent 21 March 2019. https://notices.dfo-mpo.gc.ca/fns-sap/index-eng.cfm ?pg=view_notice\&DOC_ID=219880\&ID=all

Flather CH, Knowles MS, Kendall IA (1998) Threatened and endangered species geography. BioScience 48:365-376

Fox CH, Huettmann FH, Harvey GKA, Morgan KH, Robinson J, Williams R, Paquet PC (2017) Predictions from machine learning ensembles: marine bird distribution and density on Canada's Pacific coast. Mar Ecol Prog Ser 566:199-216

Frank KT, Petrie B, Choi JS, Leggett WC (2005) Trophic cascades in a formerly cod-dominated ecosystem. Science 308:1621-1623

Furness RW (2003) Impacts of fisheries on seabird communities. Sci Mar 67(S2):33-45

*Gaston KH, David R (1994) Hotspots across Europe. Biodivers Lett 2:108-116

Gladics AJ, Melvin EF, Suryan RM, Good TP, Jannot JE, Guy TJ (2017) Fishery-specific solutions to seabird bycatch in the US West Coast sablefish fishery. Fish Res 196:85-95

Good TP, Tuttle V, Jannot J, Shama R, Riley N, McVeigh J (2015) Observed and estimated by-catch of short-tailed albatross in US West Coast groundfish fisheries, 20102013. National Marine Fisheries Service Report 6

Gould P, Ostrom P, Walker W, Pilichowski K (1998) Laysan and black-footed albatrosses: trophic relationships and driftnet fisheries associations of non-breeding birds. In: Robertson G, Gales R (eds) Albatross biology and conservation. Surrey Beatty \& Sons, Chipping Norton, p 197-207

* Granadeiro JP, Phillips RA, Brickle P, Catry P (2011) Albatrosses following fishing vessels: How badly hooked are they on an easy meal? PLOS ONE 6:e17467

Gutowsky SE, Leonard ML, Conners MG, Shaffer SA, Jonsen ID (2015) Individual-level variation and higher-level interpretations of space use in wide-ranging species: an albatross case study of sampling effects. Front Mar Sci 2:93

*Guy TJ, Jennings SL, Suryan RM, Melvin EF and others (2013) Overlap of North Pacific albatrosses with the US west coast groundfish and shrimp fisheries. Fish Res 147:222-234

*Hall SJ, Mainprize BM (2005) Managing by-catch and discards: How much progress are we making and how can we do better? Fish Fish 6:134-155

*Halpern BS, Walbridge S, Selkoe KA, Kappel CV and others (2008) A global map of human impact on marine ecosystems. Science 319:948-952

Halpern BS, Frazier M, Afflerbach J, Lowndes JS and others (2019) Recent pace of change in human impact on the world's ocean. Sci Rep 9:11609

*Harvey GKA, Nelson T, Fox CH, Paquet PC (2017) Quantifying marine mammal hotspots in British Columbia, Canada. Ecosphere 8:e01884

*Hyrenbach KD, Fernández P, Anderson DJ (2002) Oceanographic habitats of two sympatric North Pacific albatrosses during the breeding season. Mar Ecol Prog Ser 233:283-301

*Hyrenbach KD, Keiper C, Allen SG, Ainley DG, Anderson DJ (2006) Use of marine sanctuaries by far-ranging predators: commuting flights to the California Current System by breeding Hawaiian albatrosses. Fish Oceanogr 15:95-103

Jackson JB, Kirby MX, Berger WH, Bjorndal KA and others (2001) Historical overfishing and the recent collapse of coastal ecosystems. Science 293:629-637

* Jiménez S, Domingo A, Brazeiro A (2009) Seabird bycatch in the southwest Atlantic: interaction with the Uruguayan pelagic longline fishery. Polar Biol 32:187-196

Kiménez S, Domingo A, Abreu M, Brazeiro A (2012) Risk assessment and relative impact of Uruguayan pelagic longliners on seabirds. Aquat Living Resour 25:281-295

* Jiménez S, Phillips RA, Brazeiro A, Defeo O, Domingo A (2014) Bycatch of great albatrosses in pelagic longline fisheries in the southwest Atlantic: contributing factors and implications for management. Biol Conserv 171: 9-20

Kappes MA, Shaffer SA, Tremblay Y, Foley DG and others (2010) Hawaiian albatrosses track interannual variability of marine habitats in the North Pacific. Prog Oceanogr 86:246-260

Kenyon JK, Morgan KH, Bentley MD, McFarlane Tranquilla LA, Moore KE (2009) Atlas of pelagic seabirds off the west coast of Canada and adjacent areas. Tech Rep Ser 499, Canadian Wildlife Service, Pacific and Yukon Region, Delta. http://publications.gc.ca/site/eng/9.858864/ publication.html

Knowlton AR, Hamilton PK, Marx MK, Pettis HM, Kraus SD (2012) Monitoring North Atlantic right whale Eubalaena glacialis entanglement rates: a 30 yr retrospective. Mar Ecol Prog Ser 466:293-302

Laake J, Borchers D, Thomas L, Miller D, Bishop J (2013) MRDS: mark-recapture distance sampling. R package version 2.1.4. www.CRAN.R-project.org/package=mrds (accessed 10 Dec 2013)

* Laver PN, Kelly MJ (2008) A critical review of home range studies. J Wildl Manag 72:290-298

* Lewison RL, Crowder LB, Read AJ, Freeman SA (2004) Understanding impacts of fisheries bycatch on marine megafauna. Trends Ecol Evol 19:598-604 
Lewison RL, Crowder LB, Wallace BP, Moore JE and others (2014) Global patterns of marine mammal, seabird, and sea turtle bycatch reveal taxa-specific and cumulative megafauna hotspots. Proc Natl Acad Sci USA 111:5271-5276

Løkkeborg S (2011) Best practices to mitigate seabird bycatch in longline, trawl and gillnet fisheries-efficiency and practical applicability. Mar Ecol Prog Ser 435:285-303

Melvin EF, Parrish JK, Dietrich KS, Hamel OS (2003) Solutions to seabird bycatch in Alaska's demersal longline fisheries. Project A/FP-7, WSG-AS 01-01. Washington Sea Grant, Seattle, WA

* Melvin EF, Dietrich KS, Suryan RM, Fitzgerald SM (2019) Lessons from seabird conservation in Alaskan longline fisheries. Conserv Biol 33:842-852

Michael PE, Jahncke J, Hyrenbach KD (2016) Placing local aggregations in a larger-scale context: hierarchical modeling of black-footed albatross dispersion. PLOS ONE 11:e0153783

Myers RA, Worm B (2003) Rapid worldwide depletion of predatory fish communities. Nature 423:280-283

Myers N, Mittermeier RA, Mittermeier CG, Da Fonseca GA, Kent J (2000) Biodiversity hotspots for conservation priorities. Nature 403:853-858

Nelson TA, Boots B (2008) Detecting spatial hot spots in landscape ecology. Ecography 31:556-566

O'Connor AJ (2013) Distributions and fishery associations of immature short-tailed albatrosses, Pheobastria albatrus, in the North Pacific. MSc thesis, Oregon State University, Corvallis, OR

Orben RA, O'Connor AJ, Suryan RM, Ozaki K, Sato F, Deguchi T (2018) Ontogenetic changes in at-sea distributions of immature short-tailed albatrosses Phoebastria albatrus. Endang Species Res 35:23-37

*Pace ML, Cole JJ, Carpenter SR, Kitchell JF (1999) Trophic cascades revealed in diverse ecosystems. Trends Ecol Evol 14:483-488

* Petersen SL, Phillips RA, Ryan PG, Underhill LG (2008) Albatross overlap with fisheries in the Benguela Upwelling System: implications for conservation and management. Endang Species Res 5:117-127

Phillips RA, Gales R, Baker GB, Double MC and others (2016) The conservation status and priorities for albatrosses and large petrels. Biol Conserv 201:169-183

Piatt JF, Wetzel J, Bell K, DeGange AR and others (2006) Predictable hotspots and foraging habitat of the endangered short-tailed albatross (Phoebastria albatrus) in the North Pacific: implications for conservation. Deep Sea Res II 53:387-398

Pierre JP, Abraham ER, Richard Y, Cleal J, Middleton DAJ (2012) Controlling trawler waste discharge to reduce seabird mortality. Fish Res 131-133:30-38

* Pott C, Wiedenfeld DA (2017) Information gaps limit our understanding of seabird bycatch in global fisheries. Biol Conserv 210:192-204

R Core Team (2013) R: a language and environment for statistical computing. R Foundation for Statistical Computing, Vienna

Rechsteiner EU, Birdsall CFC, Sandilands D, Smith IU, Phillips AV, Barrett-Lennard LG (2013) Quantifying observer effort for opportunistically-collected wildlife sightings. BC Cetacean Sightings Network: Technical Report. Vancouver Aquarium, Vancouver, BC

Robards MD, Reeves RR (2011) The global extent and character of marine mammal consumption by humans: 19702009. Biol Conserv 144:2770-2786
Robertson G, Moreno C, Arata JA, Candy SG and others (2014) Black-browed albatross numbers in Chile increase in response to reduced mortality in fisheries. Biol Conserv 169:319-333

Roe JH, Morreale SJ, Paladino FV, Shillinger GL and others (2014) Predicting bycatch hotspots for endangered leatherback turtles on longlines in the Pacific Ocean. Proc R Soc B 281:20132559

* Roman J, Palumbi SR (2003) Whales before whaling in the North Atlantic. Science 301:508-510

* Santora JA, Sydeman WJ (2015) Persistence of hotspots and variability of seabird species richness and abundance in the southern California Current. Ecosphere 6:214

* Senko J, White ER, Heppell SS, Gerber LR (2014) Comparing bycatch mitigation strategies for vulnerable marine megafauna. Anim Conserv 17:5-18

Silverman BW (1986) Density estimation for statistics and data analysis. Chapman \& Hall, London

Smith J, Morgan KH (2005) An assessment of seabird bycatch in longline and net fisheries in British Columbia. Tech Rep Ser 401, Canadian Wildlife Service, Pacific and Yukon Region, Delta. http://publications.gc.ca/site/eng/ 9.858347/publication.html

Soriano-Redondo A, Cortés V, Reyes-González JM, Guallar S and others (2016) Relative abundance and distribution of fisheries influence risk of seabird bycatch. Sci Rep $6: 37373$

* Stahl P, Vandel JM, Herrenschmidt V, Migot P (2001) Predation on livestock by an expanding reintroduced lynx population: long-term trend and spatial variability. J Appl Ecol 38:674-687

* Studwell AJ, Hines E, Elliott ML, Howar J, Holzman B, Nur N, Jahncke J (2017) Modeling nonresident seabird foraging distributions to inform ocean zoning in central California. PLOS ONE 12:e0169517

Sullivan BJ (2004) Falkland Islands plan of action for reducing incidental catch of seabirds in trawl fisheries. Seabirds at Sea Team, Falklands Conservation, Stanley, Falkland Islands

* Suryan RM, Dietrich KS, Melvin EF, Balogh GR, Sato F, Ozaki K (2007) Migratory routes of short-tailed albatrosses: use of exclusive economic zones of North Pacific Rim countries and spatial overlap with commercial fisheries in Alaska. Biol Conserv 137:450-460

* Suryan RM, Anderson DJ, Shaffer SA, Roby DD and others (2008) Wind, waves, and wing loading: morphological specialization may limit range expansion of endangered albatrosses. PLOS ONE 3:e4016

Tasker ML, Camphuysen CJ, Cooper J, Garthe S, Montevecchi WA, Blaber SJM (2000) The impacts of fishing on marine birds. ICES J Mar Sci 57:531-547

Taylor BL, Rojas-Bracho L, Moore J, Jaramillo-Legorreta A and others (2017) Extinction is imminent for Mexico's endemic porpoise unless fishery bycatch is eliminated. Conserv Lett 10:588-595

* Thomas L, Buckland ST, Rexstad EA, Laake JL, and others (2010) Distance software: design and analysis of distance sampling surveys for estimating population size. J Appl Ecol 47:5-14

* Thorne LH, Hazen EL, Bograd SJ, Foley DG and others (2015) Foraging behavior links climate variability and reproduction in North Pacific albatrosses. Mov Ecol $3: 27$

* Thorne LH, Conners MG, Hazen EL, Bograd SJ, Antolos M, Costa DP, Shaffer SA (2016) Effects of El Niño-driven 
changes in wind patterns on North Pacific albatrosses. J R Soc Interface 13:20160196

USFWS (US Fish and Wildlife Service) (2020) Short-tailed albatross (Phoebastria albatrus) 5-year review: summary and evaluation. USFWS, Anchorage, AK

Wagner EL, Boersma PD (2011) Effects of fisheries on seabird community ecology. Rev Fish Sci 19:157-167

Wasser SK, Lundin JI, Ayres K, Seely E and others (2017) Population growth is limited by nutritional impacts on pregnancy success in endangered southern resident killer whales (Orcinus orca). PLOS ONE 12:e0179824

Weimerskirch H, Guionnet T, Martin J, Shaffer SA, Costa DP (2000) Fast and fuel-efficient? Optimal use of wind by flying albatrosses. Proc Biol Sci 267:1869-1874

Wiese FK, Smith JL (2003) Mortality estimates and population effects of Canadian Pacific longline fisheries on black-footed albatross (Phoebastria nigripes): national and international implications. Can Tech Rep Fish Aquat Sci 2471:23-50

Editorial responsibility: Robert M. Suryan

Juneau, Alaska, USA

Reviewed by: J. L Smith, T. Good and 1 anonymous referee
Wood AG, Naef-Daenzer B, Prince PA, Croxall JP (2000) Quantifying habitat use in satellite-tracked pelagic seabirds: application of kernel estimation to albatross locations. J Avian Biol 31:278-286

Worton BJ (1995) A convex hull-based estimator of homerange size. Biometrics 51:1206-1215

* Wren JLK, Shaffer SA, Polovina JJ (2019) Variations in blackfooted albatross sightings in a North Pacific transitional area due to changes in fleet dynamics and oceanography 2006-2017. Deep Sea Res II 169-170:104605

* Yamanaka KL, Logan G (2010) Developing British Columbia's inshore rockfish conservation strategy. Mar Coast Fish 2:28-46

Zacharias MA, Gregr EJ (2005) Sensitivity and vulnerability in marine environments: an approach to identifying vulnerable marine areas. Conserv Biol 19:86-97

*̌y̆ydelis R, Small C, French G (2013) The incidental catch of seabirds in gillnet fisheries: a global review. Biol Conserv 162:76-88

Submitted: October 16, 2020

Accepted: June 7, 2021

Proofs received from author(s): August 15, 2021 